ACTA UNIVERSITATIS LODZIENSIS

FOLIA LITTERARIA POLONICA 1(39) 2017

http://dx.doi.org/10.18778/1505-9057.39.13

Urszula Doliwa*

\title{
Serwis informacyjny jako ważny element realizacji misji regionalnych rozgłośni radiowych na przykładzie Radia Olsztyn
}

\section{Regionalne rozgłośnie radiowe Polskiego Radia}

Początki polskiej radiofonii sięgają dwudziestolecia międzywojennego. Przypomnijmy, że szlaki w dziedzinie nadawania przekazu radiowego najpierw przecierało Polskie Towarzystwo Radiotechniczne, ale to Polskie Radio otrzymało wyłączną koncesję na nadawanie i w 1926 roku rozpoczęło regularną emisję programów. Bardzo szybko też zaczęto organizować rozgłośnie regionalne. Choć, jak donosił Maciej Kwiatkowski, sytuacja Polskiego Radia na początku jego istnienia wcale nie należała do łatwych - abonentów było niewielu, a i ci zarejestrowani często zalegali z opłatami - szybko przystąpiono do budowy stacji w większych polskich miastach. W 1927 roku powstały cztery takie rozgłośnie - w Krakowie, Poznaniu, Katowicach i Wilnie'. Liczba ta stale rosła i do 1939 roku powiększyła się o Lwów, Łódź, Baranowicze, Toruń i Warszawę. Budowę kolejnych przerwała wojna.

Sieć regionalnych rozgłośni szybko po wojnie odbudowano - choć w innym już kształcie - dopasowanym do nowych granic. Jednym z naczelnych powodów szybkiego ich uruchomienia po wojnie z pewnością była potrzeba rozpowszechniania treści propagandowych - nie sposób jednak tym rozgłośniom odmówić pełnienia ważnych funkcji informacyjnych, edukacyjnych i integracyjnych. Znaczącą zmianę w kształcie i modelu funkcjonowania rozgłośni regionalnych przyniosło przyjęcie Ustawy o radiofonii i telewizji ${ }^{2}$. Na mocy tej ustawy rozgłośnie radia publicznego zyskały odrębną osobowość prawną - stały się niezależnymi spółkami.

* Dr hab., e-mail: urszula.doliwa@uwm.edu.pl; Uniwersytet Warmińsko-Mazurski w Olsztynie, Instytut Dziennikarstwa i Komunikacji Społecznej; 10-725 Olsztyn, ul. Kurta Obitza 1.

${ }^{1}$ M. Kwiatkowski, Tu Polskie Radio Warszawa..., Państwowy Instytut Wydawniczy, Warszawa 1980 , s. 110.

${ }^{2}$ Ustawa z dnia 29 grudnia 1992 roku o radiofonii i telewizji z późniejszymi zmianami, http://. isap.sejm.gov.pl/Download?id=WDU20042532531\&type=3 [dostęp: 10.05.2015]. 


\section{Misja regionalnych rozgłośni radia publicznego w kontekście informacji przekazywanych na antenie rozgłośni regionalnych}

Zgodnie z Ustawą o radiofonii i telewizji rozgłośnie publiczne, w tym regionalne rozgłośnie Polskiego Radia, zobowiązane są pełnić tak zwaną misję publiczną ${ }^{3}$ W art. 21 ust. 2 określono wymagania programowe wobec nadawców publicznych, których audycje powinny:

- kierować się odpowiedzialnością za słowo i dbać o dobre imię publicznej radiofonii i telewizji;

- rzetelnie ukazywać całą różnorodność wydarzeń i zjawisk w kraju i za granicą;

- sprzyjać swobodnemu kształtowaniu się poglądów obywateli oraz formowaniu się opinii publicznej;

- umożliwiać obywatelom i ich organizacjom uczestniczenie w życiu publicznym poprzez prezentowanie zróżnicowanych poglądów i stanowisk oraz wykonywanie prawa do kontroli i krytyki społecznej;

- służyć rozwojowi kultury, nauki i oświaty, ze szczególnym uwzględnieniem polskiego dorobku intelektualnego i artystycznego;

- respektować chrześcijański system wartości, za podstawę przyjmując uniwersalne zasady etyki;

- służyć umacnianiu rodziny;

- służyć kształtowaniu postaw prozdrowotnych;

- służyć zwalczaniu patologii społecznych.

$Z$ badań przeprowadzonych na zlecenie Krajowej Rady Radiofonii i Telewizji w 2004 roku wynikało, że według $42 \%$ badanych radio publiczne ma szczególne zadania wobec społeczeństwa. Jedna czwarta badanych wyraziła przeciwny pogląd, natomiast blisko jedna trzecia nie miała zdania na ten temat. Wskazywano na kilka typów audycji, które powinny być obecne w radiu publicznym, wśród których informacyjne znalazły się na pierwszym miejscu [w dalszej kolejności wymieniano edukacyjne, kulturalne, reportaże i publicystykę]. Respondenci podawali również ogólne cechy, jakimi powinno się charakteryzować radio publiczne - do najważniejszych zaliczyli rzetelność i obiektywizm ${ }^{4}$.

Misja regionalnych mediów publicznych nie została doprecyzowana w Ustawie, była jednak przedmiotem rozważań w innych dokumentach - przykładem może być załącznik do uchwały Krajowej Rady Radiofonii i Telewizji nr 44 z 3 lutego 2004 roku, w którym czytamy:

\footnotetext{
${ }^{3}$ Ustawa...

${ }^{4}$ KRRiT, Informacja o podstawowych problemach radiofonii i telewizji, 2005, http://www. krrit.gov.pl/Data/Files/_public/Portals/0/sprawozdania/spr2005/inf2005.pdf [dostęp: 20.05.2016].
} 
Zadaniem regionalnego radia publicznego jest realizacja tzw. misji regionalnej, rozumianej jako zaspokajanie potrzeb mieszkańców regionu, dla którego nadawany jest program, w dziedzinie informacji, objaśniania, poradnictwa oraz wymiany poglądów i opinii na tematy dotyczące życia danego regionu - społecznego, gospodarczego, politycznego, szeroko pojętej kultury, nauki, sportu i rekreacji, a także informowanie o wydarzeniach i sprawach ogólnokrajowych i zagranicznych oraz dyskutowanie o nich i wyrażanie opinii - zwłaszcza w aspekcie ich znaczenia dla regionu ${ }^{5}$.

$\mathrm{Na}$ znaczenie informacji w działalności rozgłośni regionalnej zwraca też uwagę Edward Chudziński, który podkreśla, że informacyjna funkcja regionalnych rozgłośni radia publicznego powinna być realizowana poprzez tworzenie wiarygodnej, szybkiej, aktualnej i jak najpełniejszej informacji typu dziennikarskiego i specjalistycznego ${ }^{6}$. Radio regionalne pełni również funkcję kontrolną. Ma obowiązek, podobnie jak wszystkie media publiczne, „umożliwiać obywatelom i organizacjom uczestniczenie w życiu publicznym poprzez prezentowanie zróżnicowanych poglądów i stanowisk oraz wykonywanie prawa do kontroli i krytyki społecznej"7. Zdaniem Jana Beliczyńskiego, niezbędne są tu np. relacje reporterskie z sesji samorządów powiatowych i wojewódzkich, wywiady z lokalnymi działaczami politycznymi. Integracja społeczności lokalnej to również ważny element działalności radia regionalnego. Media regionalne są też silnie związane z kulturalnym i społecznym życiem swojego regionu ${ }^{8}$.

Jedną z głównych cech rozgłośni regionalnych, odróżniających je od ogólnopolskich rozgłośni radia publicznego, jest ich lokalny charakter. Owa „lokalność” radia polega zaś zdaniem Beliczyńskiego na podawaniu na antenie „zarówno wiadomości i relacji, które są ważne dla słuchaczy w danym regionie, jak i opinii samych słuchaczy. W działaniach pozaantenowych lokalność radia przejawia się we wspieraniu inicjatyw środowiska lokalnego i uczestniczeniu w jego przedsięwzięciach".

${ }^{5}$ Załącznik nr 1 do uchwały KRRiT nr 44/2004 z 3 lutego 2004 r. Cyt. za: E. Chudziński, Regionalizm - idea - ludzie - instytucje, Muzeum Niepodległości, Mazowiecka Oficyna Wydawnicza, Warszawa 2013, s. 143-144.

${ }^{6}$ Zob. E. Chudziński, Misja regionalnego radia publicznego, „Studia Medioznawcze” 2006, nr 3, s. 49-57.

${ }^{7}$ Ustawa...

${ }^{8}$ Zob. J. Beliczyński, Misja i wizja regionalnego radia publicznego, „Studia Medioznawcze” 2006, nr 3, s. 32-47.

${ }^{9}$ J. Beliczyński, Radio jako obiekt zarządzania, Wydawnictwo Akademii Ekonomicznej, Kraków 2005, s. 28. 


\section{Radio Olsztyn i realizacja przez rozglośnię funkcji informacyjnej}

Radio Olsztyn - publiczna rozgłośnia regionalna - obejmuje swoim zasięgiem przede wszystkim województwo warmińsko-mazurskie. Początkowo w 1952 roku w Olsztynie powstała jedynie Ekspozytura Polskiego Radia. Dopiero w 1958 roku przekształcono ją w rozgłośnię regionalną Polskiego Radia. Samodzielną osobowość prawną, podobnie jak inne rozgłośnie regionalne, stacja uzyskała na mocy Ustawy o radiofonii i telewizji w 1992 roku $^{10}$.

Rozgłośnia - jako medium publiczne - jest zobowiązana do pełnienia misji programowej, której ważną częścią jest przekazywanie informacji. Serwisy informacyjne nadawane są w Radiu Olsztyn o każdej pełnej godzinie. Dodatkowo w godzinach największej słuchalności w dni powszednie emitowane są serwisy w połowie godziny: o $6.30,7.30,8.30,15.30$. Niektóre wydania poprzedzone są skrótem informacji. W serwisach przede wszystkim prezentowane są informacje lokalne, ale jest w nich również miejsce na krajowe i światowe. Informacje lokalne przygotowywane są przez dziennikarzy Radia Olsztyn, informacje krajowe i światowe pochodzą głównie z Informacyjnej Agencji Radiowej [IAR], czasami również z Polskiej Agencji Prasowej czy innych źródeł. Na etacie w tzw. newsroomie w Olsztynie zatrudnionych jest siedem osób. Radio Olsztyn posiada również dwie redakcje terenowe: elbląską [w której pracują cztery osoby] i ełcką [w której zatrudnione są dwie osoby]. Z rozgłośnią współpracują również korespondenci z Nowego Miasta Lubawskiego, Działdowa, Lidzbarka Warmińskiego, Bartoszyc. Na serwis składają się jednak również informacje spływające ze wszystkich redakcji i od innych dziennikarzy Radia Olsztyn. Od 6.00 do 12.00, w dzień powszedni, nad przygotowaniem i odczytywaniem serwisów na antenie Radia Olsztyn, czuwają dwie osoby - kobieta i mężczyzna. Od 12.00 do 19.00 lektora zazwyczaj wspiera asystent, który pomaga mu zbierać i opracowywać informacje.

${ }^{10}$ Więcej informacji na temat historii Radia Olszyn zob. m.in.: M. Kropacz-Szydłowska, Od Ekspozytury Polskiego Radia do Radia Olsztyn S.A. Z dziejów olsztyńskiej radiofonii w latach 1952-1993, Polskie Towarzystwo Historyczne. Oddział: Instytut Dziennikarstwa i Komunikacji Społecznej UWM, Olsztyn 2012; R. Langowski, Pięćdziesięciolecie czyli podróż nieco sentymentalna, Pracownia Wydawnicza „ElSet”, Olsztyn 2002; W. Ogrodziński, B. Żmijewski, Radio Olsztyn od 60 lat... naturalnie, Pracownia Wydawnicza „ElSet”, Olsztyn 2012. 


\section{Opis badań}

Analizie zostały poddane serwisy informacyjne z dwóch tygodni od 16.09.2015 do 22.09.2015 i od 13.04.2016 do 19.04.2016 nadawane o następujących godzinach: $7.00,7.30,8.00,8.30,12.00,15.00,16.00$. Zastosowano tu dobór celowy: są to $\mathrm{z}$ uwagi na porę emisji [poranny i popołudniowy prime time] najważniejsze wydania, którym redakcja poświęca też najwięcej uwagi. W przypadku serwisów z 2015 roku było to 221 informacji, a w przypadku 2016 roku - 200 informacji. W sumie analizie poddano więc 421 informacji. Analiza miała zarówno ilościowy, jak i jakościowy charakter. Materiał do badań z 2015 roku został przekazany przez Radio Olsztyn w postaci wydruków z systemu emisyjnego. W przypadku serwisów emitowanych w 2016 roku były to jedynie nagrania serwisów.

\section{Główne cele badania}

Każda analiza powinna być poprzedzona określeniem głównych celów badawczych. W prowadzonym badaniu wyróżniono dwa takie cele:

1. Sprawdzenie, pod kątem różnych parametrów, omówionych w dalszej części artykułu, kształtu serwisów informacyjnych.

2. Ocena jakości tych serwisów w kontekście realizacji przez nadawcę misji publicznej.

By ocenę jakości serwisów jak najbardziej zobiektywizować, zdecydowano się na wskazanie pewnych pytań badawczych i kryteriów, które uznano za czynniki mogące mieć wpływ na ich ocenę:

1. Czy serwis ma charakter zróżnicowany pod względem tematycznym, gatunkowym, zasięgu informacji, doboru gości zapraszanych w charakterze ekspertów?

2. Czy informacje są wolne od różnego rodzaju błędów: natury językowej, technicznej, konstrukcyjnej czy też w zakresie prozodii przekazu?

Proces analizy badanych materiałów

Badane serwisy informacyjne Radia Olsztyn zostały przeanalizowane pod kątem następujących parametrów:

- parametr pierwszy: godzina emisji;

- parametr drugi: data emisji;

- parametr trzeci: autor informacji [możliwy do wskazania tylko w przypadku materiałów do analizy przekazanych w postaci wydruków komputerowych];

- parametr czwarty: miejsce w serwisie, na którym prezentowana była dana informacja;

- parametr piąty: gatunek informacji;

- parametr szósty: zasięg informacji; 
- parametr siódmy: miejsce, którego dana informacja dotyczyła [kraj, miasto];

- parametr ósmy: tematyka informacji;

- parametr dziewiąty: inspiracja do powstania informacji [z kalendarza/nie z kalendarza];

- parametr dziesiąty: płeć eksperta;

- parametr jedenasty: sprawowana przez eksperta funkcja;

- parametr dwunasty: obecność elementów autopromocyjnych;

- parametr trzynasty: błędy występujące w prezentowanych serwisach;

- parametr czternasty: czy materiał został powtórzony.

Dodatkowo sprawdzono czas trwania poszczególnych serwisów. Dane te, z zastosowaniem odpowiedniego kodowania, wprowadzono do arkusza kalkulacyjnego Excel, co ułatwiło ich analizę. Jednostką analizy była pojedyncza informacja. Badanie jakościowe zawierało m.in. elementy analizy językowej, zrozumiałości przekazu, konstrukcji informacji i sposobu ich prezentacji.

\section{Analiza serwisów Radia Olsztyn}

\section{Zasięg terytorialny informacji}

W monitorowanych serwisach nadawanych zarówno w 2015, jak i 2016 roku koncentrowano się na informacjach lokalnych, co jest zgodne z oczekiwaniami zarówno ustawodawcy, regulatora rynku, jak i słuchaczy rozgłośni regionalnych.

Wykres 1. Zasięg informacji w serwisach Radia Olsztyn [2015]

\section{Zasięg informacji}

2015

155

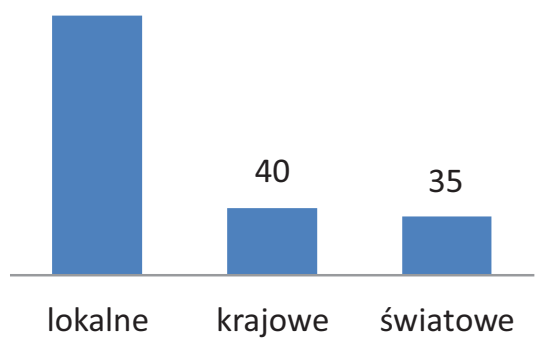

Źródło: badania własne. 
Wykres 2. Zasięg informacji w serwisach Radia Olsztyn [2016]

\section{Zasięg informacji}

2016

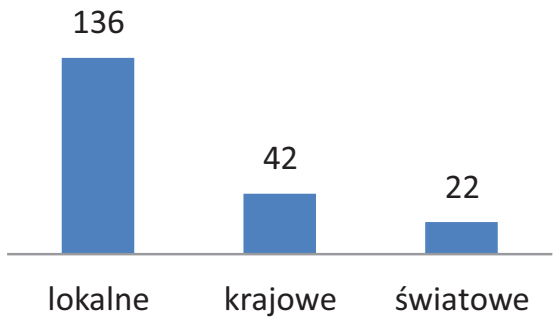

Źródło: badania własne.

W przypadku informacji ze świata nadanych w 2015 roku na uwagę zasługuje fakt, że zdominowane zostały one przez temat uchodźców. Aż 14, a więc niemal połowa, dotyczyła tej kwestii. Drugim tematem, którym wyjątkowo często zajmowano się na antenie w wymiarze światowym, mającym jednak istotne przełożenie na sprawy lokalne, była reakcja na demontaż pomnika radzieckiego bohatera w Pieniężnie [wyemitowano w badanym okresie cztery tego typu informacje]. Co ciekawe, te dwa tematy zdominowały też informacje o zasięgu krajowym. Uchodźców dotyczyło aż 10 informacji krajowych, a aż 6 dotyczyło demontażu pomnika.

W przypadku informacji emitowanych w 2016 roku temat uchodźców wciąż był obecny w doniesieniach ze świata prezentowanych w Radiu Olsztyn, choć informacji na ten temat pojawiło się zdecydowanie mniej [3 informacje]. Inną ważną wiadomością okazała się ta o uformowaniu nowego rządu na Ukrainie [3 informacje]. Jeżeli chodzi o informacje krajowe, to zdominował je temat obchodów okrągłej rocznicy chrztu Polski [10 informacji].

Bardziej szczegółowo zdecydowano się przeanalizować tematykę informacji lokalnych, gdyż to one są tworzone przez dziennikarzy Radia Olsztyn - krajowe i światowe przychodzą z reguły z Informacyjnej Agencji Radiowej - do dziennikarzy w Olsztynie należy natomiast ich selekcja i dopasowanie do potrzeb serwisu regionalnego. I tak dziennikarze Radia Olsztyn, jak można się było spodziewać, koncentrowali uwagę na informacjach z Olsztyna. Co jednak warto podkreślić, podawali informacje dotyczące także wielu innych miast i miasteczek z regionu, starając się jak najlepiej wywiązać ze swojej misji nadawcy regionalnego, która w przypadku Radia Olsztyn jest bardzo trudna do wypełnienia z uwagi na rozległość województwa warmińsko-mazurskiego. W sumie informacje z Olsztyna zarówno w 2015, jak i 2016 roku stanowiły około 1/3 wszystkich. Zwracała też uwagę duża liczba informacji z Elbląga, na co z pewnością duży wpływ miało funkcjonowanie studia Radia Olsztyn w Elblągu. 
Wykres 3. Miasta, których najczęściej dotyczyły informacje emitowane w badanych serwisach Radia Olsztyn [2015] ${ }^{11}$

\section{Reprezentowane miasta}

2015

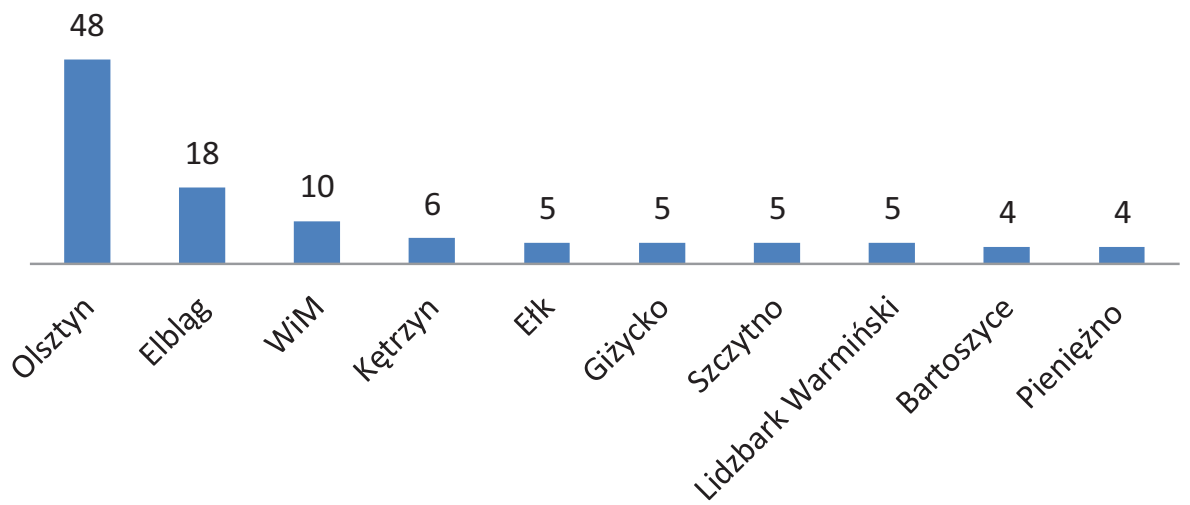

Źródło: badania własne.

Wykres 4. Miasta, których najczęściej dotyczyły informacje emitowane w badanych serwisach Radia Olsztyn [2016] ${ }^{12}$

\section{Reprezentowane miasta}

2016

\section{0}

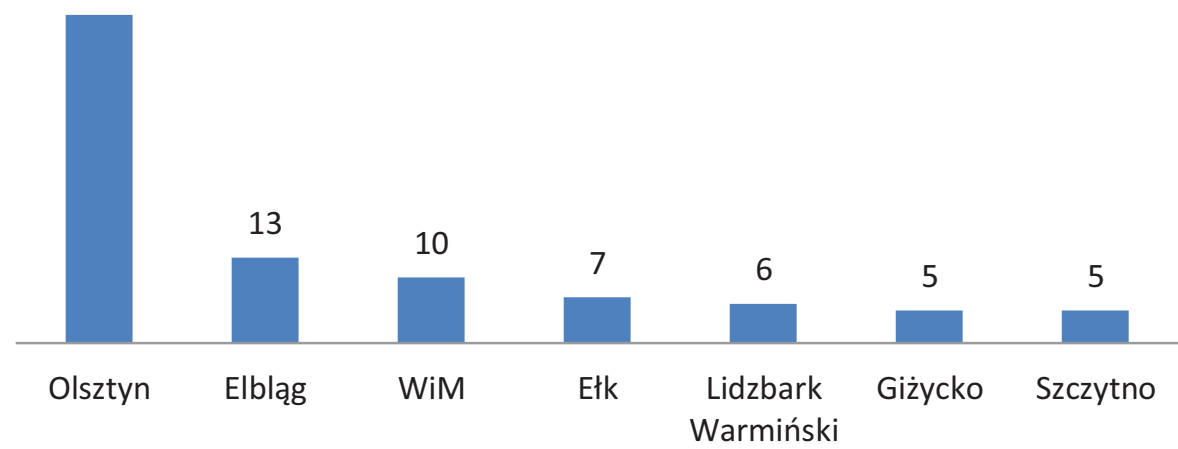

Źródło: badania własne.

\footnotetext{
${ }^{11}$ WiM - informacje dotyczące całego regionu Warmii i Mazur.
}

${ }^{12} \mathrm{WiM}$ - informacje dotyczące całego regionu Warmii i Mazur. 


\section{Gatunki informacji}

W dalszej części analizy postanowiono skupić się przede wszystkim na informacjach lokalnych, które zazwyczaj od początku są tworzone przez dziennikarzy pracujących dla olsztyńskiej rozgłośni lub współpracujących z nią. Jednym z pytań szczegółowych, które wydały się interesujące w kontekście postawionych pytań badawczych, było to dotyczące gatunków informacji nadawanych w serwisach. Wyróżniono tu cztery podstawowe gatunki informacji radiowej: informację prostą - czytaną przez lektora ze studia, informację z dźwiękiem również prezentowaną przez lektora ze studia, w którą jednak wplecione są wypowiedzi innych osób lub tzw. obrazek, czyli tło dźwiękowe nagrane w miejscu zdarzenia, relację reportera oraz tzw. paszczodźwięk, który jest odmianą relacji reportera poprzeplatanej zebranymi przez niego wypowiedziami innych osób lub innymi dźwiękami.

Wykres 5. Gatunki informacji w serwisach Radia Olsztyn [2015]

\section{Gatunek informacji \\ 2015}

81
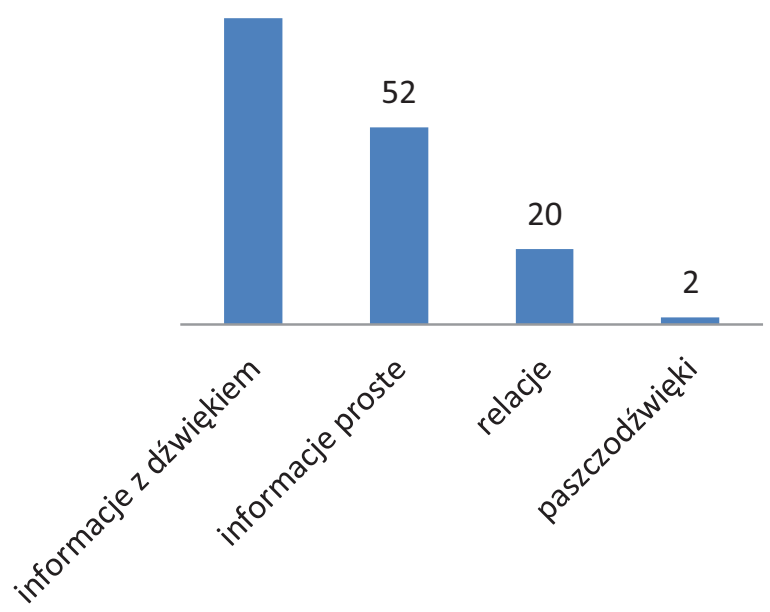

Źródło: badania własne. 
Wykres 6. Gatunki informacji w serwisach Radia Olsztyn [2016]

\section{Gatunki informacji \\ 2016}

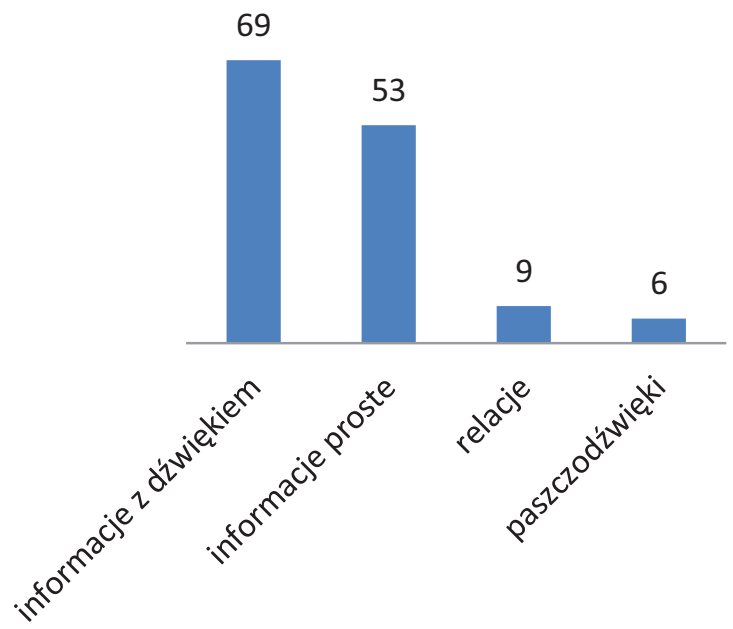

Źródło: badania własne.

O wysokiej jakości serwisów przygotowywanych przez Radio Olsztyn w badanym okresie świadczy duża liczba informacji z ilustracją dźwiękową. Są one bardziej pracochłonne i kosztowne w przygotowaniu niż te odczytywane jedynie ze studia. Proste informacje pisane stanowią mniejszość. Przyglądając się dwóm powyższym wykresom, warto jednak zwrócić uwagę na fakt, że liczba informacji z dźwiękiem spadła w 2016 roku. Można też zaobserwować niewielką liczbę relacji reportera, zwłaszcza w monitorowanych serwisach z 2016 roku i bardzo małą liczbę paszczodźwięków.

\section{Źródła informacji}

W Radiu Olsztyn, podobnie jak w innych rozgłośniach, prowadzony jest tzw. kalendarz, do którego wpisuje się wcześniej planowane wydarzenia, np. wystawy, koncerty, rozprawy w sądzie itp. Część z nich trafia później do serwisu. Zazwyczaj jednak najbardziej interesujące słuchaczy informacje to wiadomości, które nie dotyczą wcześniej zaplanowanych zdarzeń, o których Radio Olsztyn zostało poinformowane czy na które dziennikarze rozgłośni zostali zaproszeni. Najciekawsze informacje to często jednak takie, które różne osoby starają się przed dziennikarzami ukryć. I tak spośród badanych informacji lokalnych nadanych w 2015 roku aż 97 zakwalifikowano jako informacje z kalendarza, a w 2016 roku było ich 78, co stanowiło odpowiednio $62 \%$ i $57 \%$ wszystkich nadanych w monitorowanym okresie. 


\section{Tematyka informacji lokalnych}

W serwisie pojawiały się informacje różnorodne tematycznie. Nadreprezentacja niektórych kategorii tematycznych może jednak zaskakiwać.

Wykres 7. Tematyka informacji wyemitowanych w badanych serwisach [2015]

\section{Tematyka}

2015

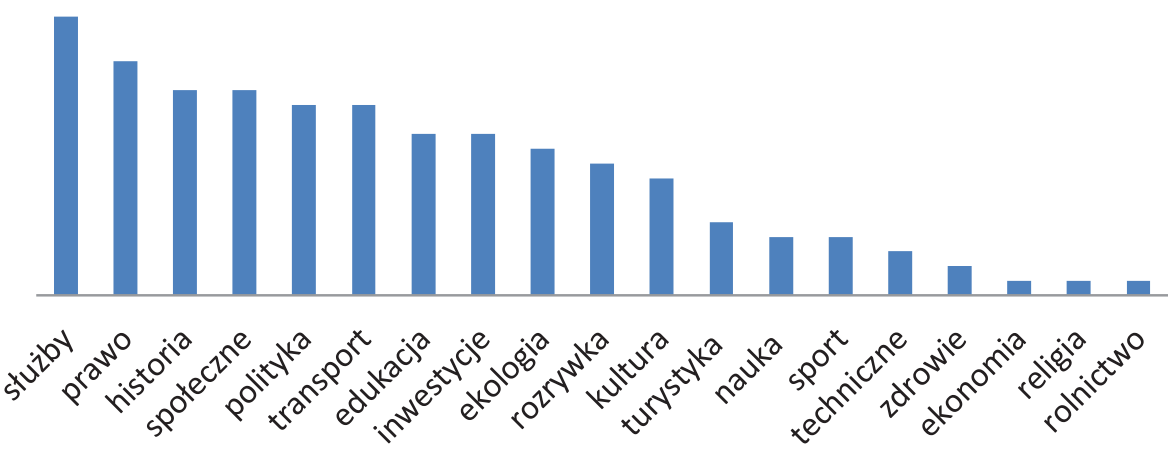

Źródło: badania własne.

W przypadku informacji nadawanych w 2015 roku warto z pewnością zwrócić uwagę na fakt, że najwięcej pochodziło od służb mundurowych: policjantów, strażaków, służby celnej itp. Były to np. wiadomości na temat wypadków, pożarów, zatrzymań, prób przemytu. Mówiono jednak również dużo o różnych aspektach działalności tych służb. Tylko w tym jednym monitorowanym tygodniu z 2015 roku informowano o: jubileuszu związku policjantów, dwuboju pożarniczym, Dniu Służby Celnej, zawodach policjantów i protestach służb mundurowych przeciwko zbyt niskim płacom. Biorąc pod uwagę fakt, że niekiedy pojawiało się nawet kilka informacji na temat wspomnianych wydarzeń, słuchacz mógł mieć wrażenie przesytu. Często też informowano o przebiegu procesów sądowych i obchodach różnych rocznic historycznych. W 2015 roku w serwisie znalazło się też wiele informacji politycznych. Należy jednak pamiętać, że poddany analizie materiał badawczy pochodził z okresu przedwyborczego - wybory do Sejmu i Senatu Rzeczpospolitej Polskiej odbyły się bowiem 25 października 2015 roku.

Nieco inny rozkład tematyczny monitorowanych informacji zaobserwowano w 2016 roku. 
Wykres 8. Tematyka informacji wyemitowanych w badanych serwisach [2016]

\section{Tematyka}

2016

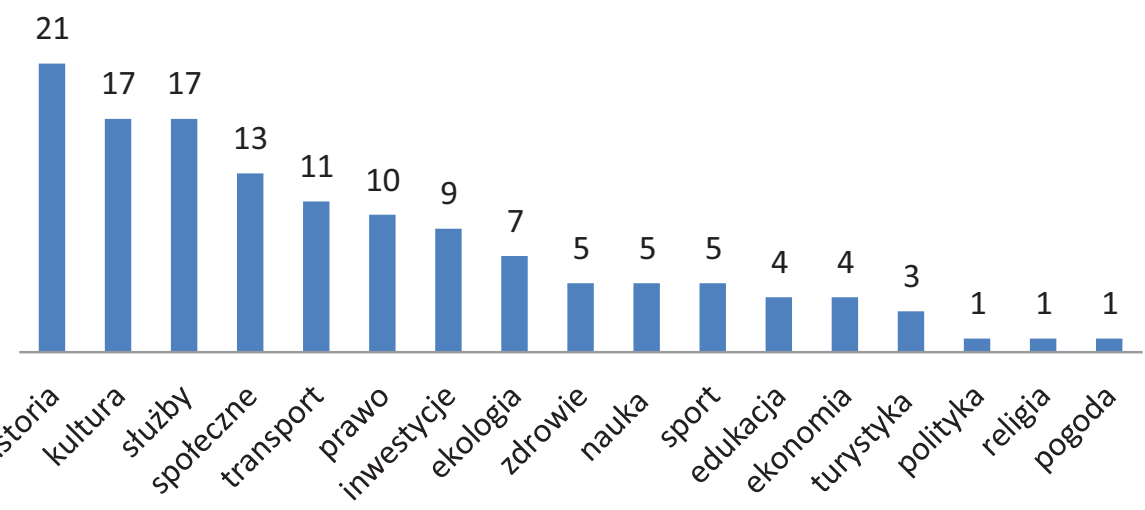

Źródło: badania własne.

Na dużą liczbę informacji o tematyce historycznej wpłynęły rocznice, które przypadały w badanym okresie, w szczególności rocznica chrztu Polski i Dzień Pamięci o Ofiarach Zbrodni Katyńskiej przypadający 13 kwietnia. Ważne dla twórców serwisu okazały się też wydarzenia kulturalne. Informowano o nagrodach literackich, teatralnych, muzycznych, koncertach i wystawach. Nadal znaczącą część serwisu stanowiły informacje przekazane przez służby mundurowe. Tym razem informowano jednak głównie o wypadkach, pożarach, incydentach związanych z łamaniem przepisów. W ten nurt nie wpisywała się jedynie wiadomość o konkursie policyjnym i komisji kwalifikacyjnej do wojska.

\section{Dobór ekspertów}

Warto również zwrócić uwagę na dobór ekspertów wypowiadających się w dźwiękach, którymi urozmaicano serwis. Biorąc pod uwagę fakt, że media publiczne zobowiązane są do tego, by służyć „,całemu społeczeństwu i poszczególnym jego częściom"13, można zadać np. pytanie, czy równowaga płci w tym aspekcie jest zachowana. Z przeprowadzonych badań wynika, że udział kobiet występujących w roli ekspertów jest stosunkowo duży i wykazuje tendencję wzrostową.

\footnotetext{
${ }^{13}$ Art. 21 Ustawy o radiofonii...
} 
Wykres 9. Płeć ekspertów wypowiadających się w serwisach Radia Olsztyn [2015]

\section{Płeć ekspertów}

2015

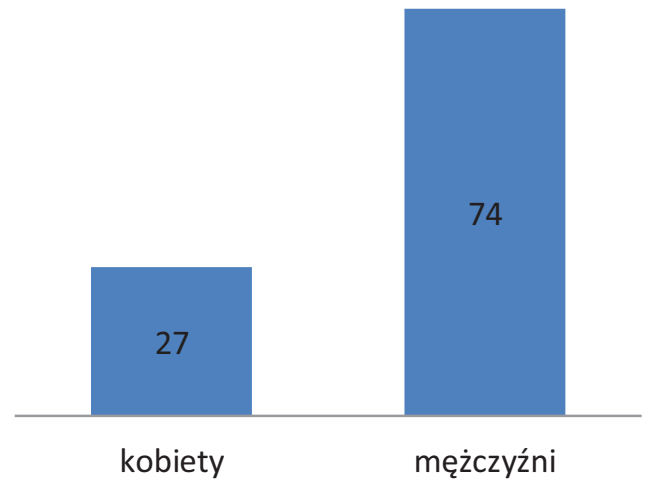

Źródło: badania własne.

Wykres 10. Płeć ekspertów wypowiadających się w serwisach Radia Olsztyn [2016]

\section{Płeć ekspertów}

2016

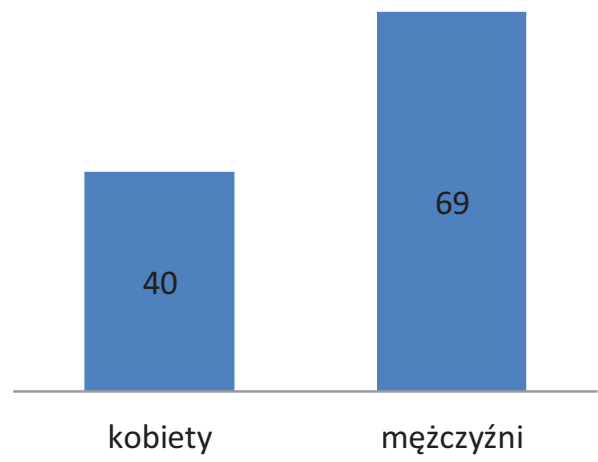

Źródło: badania własne. 
Warto też zadać pytanie, kim są osoby wypowiadające się do mikrofonu. $\mathrm{Z}$ reguły są to postaci sprawujące kierownicze stanowiska, urzędnicy, przedstawiciele służb, organizatorzy różnych przedsięwzięć, rzecznicy prasowi, artyści, prawnicy. Znacznie rzadziej byli to przedstawiciele organizacji pozarządowych. W badanym materiale z 2015 roku tylko trzech, a z 2016 roku czterech przedstawicieli świata nauki zostało poproszonych o wypowiedź do mikrofonu.

\section{Autopromocja}

Radio Olsztyn wykorzystuje również serwisy do autopromocji, co jest zgodne $\mathrm{z}$ obecnym trendem obowiązującym w serwisach informacyjnych. Jak podkreśla Krzysztof Kaszewski, media w dzisiejszych czasach muszą być promowane jak każdy inny towar, a serwisy informacyjne, które są swoistą wizytówką stacji, są świetnym nośnikiem treści autopromocyjnych. Za takie zaś Kaszewski uznaje treści, które odnoszą się do stacji radiowej, czyli nadawcy [bezpośrednio lub pośrednio] i nie wiążą się bezpośrednio z głównym tematem newsa [ich usunięcie nie spowodowałoby zubożenia zasadniczej treści przekazu] $]^{14}$. Podstawowym nośnikiem owej autopromocji są dżingle przed serwisem i po serwisie informujące o tym, że odbiorcy słuchają wiadomości Radia Olsztyn, a po informacjach z miast regionu często pojawiają się dżingle z komunikatem, na jakiej częstotliwości można słuchać radia w danym mieście. Niekiedy w badanych serwisach pojawiał się dżingiel „Więcej informacji na stronie internetowej Radia Olsztyn www.ro.com.pl". Emitowany był on jednak stosunkowo rzadko.

Nazwa radia niekiedy bywała wymieniana także $w$ treści informacji. W 2015 roku np. w zwrocie ,,jak poinformował Radio Olsztyn...” albo „rozmawiał reporter Radia Olsztyn”, ,jak podkreśla w rozmowie z reporterem Radia Olsztyn” czy też „sprawą od samego początku zajmuje się Radio Olsztyn”. Zdarzały się też odesłania do konkretnych audycji: „Problem opisaliśmy w audycji Śliska sprawa”, „Przyszłość krajowej 16 była tematem audycji Porozmawiajmy”, „Przypomnijmy, że Małgorzata Kidawa-Błońska będzie naszym gościem w Porannych pytaniach”, „Więcej na ten temat już za chwilę w Popołudniówce”. Tego typu odniesień było jednak niewiele. Serwis wykorzystywano też do poinformowania słuchaczy o remoncie nadajnika i przerwach w nadawaniu. W 2016 roku chwalono się sukcesem „redakcyjnego kolegi” Łukasza Staniszewskiego w konkursie literackim. Informowano też, że patronem medialnym konferencji było Radio Olsztyn.

\footnotetext{
${ }^{14}$ K. Kaszewski, Elementy autoprezentacyjne $w$ serwisie informacyjnym radia lokalnego, „Studia Medioznawcze” 2016, nr 1 (64), s. 89-103.
} 


\section{Usterki}

Z uwagi na fakt, że monitorowane serwisy z 2015 roku zostały przekazane jedynie w postaci wydruków, a serwisy z 2016 roku jedynie w formie nagrań, wnioski, które udało się uzyskać z prowadzonych badań, nie mogą być traktowane jako materiał do porównań w zakresie jakości serwisów w tych dwóch okresach. Jeżeli chodzi o usterki natury językowej, więcej ich stwierdzono w przypadku informacji z 2015 roku, co nie oznacza jednak, że w 2016 roku było ich mniej. Pisana wersja informacji ułatwia znalezienie takich usterek, podczas gdy w wersji dźwiękowej znacznie trudniej jest wykryć tego rodzaju błędy. Warto jednak podkreślić, że poziom serwisów przygotowywanych przez Radio Olsztyn pod względem językowym był wysoki. Rzadko zdarzały się jakieś błędy i raczej nie powinny mieć one wpływu na ogólnie pozytywną ocenę serwisów pod tym względem. Potwierdza to fakt, że w wersji dźwiękowej znacznie trudniej było je wychwycić niż w wersji pisanej - nie miały one więc dużego wpływu na odbiór. Analizując teksty pod względem językowym, nie brano pod uwagę usterek o charakterze interpunkcyjnym, ortograficznym czy też tzw. literówek w czytanych tekstach - nie mają one bowiem bezpośredniego przełożenia na wersję czytaną serwisu. Trzeba też wziąć pod uwagę fakt, że teksty informacji są pisane pod dużą presją czasu i tego typu błędy są do pewnego stopnia zrozumiałe.

Język serwisów informacyjnych prezentowanych w Radiu Olsztyn jest językiem przyjaznym słuchaczowi, prostym, ale z pewnością nie prostackim. Dobrze wpisuje się zarówno we współczesne trendy dziennikarskie, jak i misję radia publicznego, do wypełniania której Polskie Radio jest zobowiązane. Usterki w tym zakresie są nieliczne i mało znaczące. W 2015 roku stwierdzono np. błędy typu powtórzenie - słowo użyte w poprzednim zdaniu powtarzało się również w kolejnym. Pojawiły się też błędy składniowe, np.: „zgłosić się na ostatnią chwilę", a powinno być „,w ostatniej chwili”. Znaleziono też przykłady użycia strony biernej, której raczej należy unikać w tekstach radiowych. Pojawiły się takie wyrażenia, jak: ,został udostępniony mieszkańcom”, „dopływ z wodociągu w Bukwałdzie został odcięty”. Niekiedy z kolei tendencja do upraszczania języka informacji prowadziła do zbyt dużych skrótów myślowych, np. w zdaniu: „Sąd aresztował mężczyznę”. Czasami do serwisu przenikały określenia specjalistyczne, których w radiu powinno się raczej unikać: „Sąd orzekł też dwa dodatkowe środki karne". Zdarzało się również, że zdania użyte w serwisach były nadmiernie skomplikowane i nie do końca poprawne językowo, choć dałoby się te same informacje przekazać prościej. Za przykład może posłużyć informacja o procesie byłego prezydenta Olsztyna. „Były prezydent Olsztyna został uniewinniony z zarzutu molestowania, a drugi z zarzutów molestowania sąd umorzył z powodu przedawnienia”, podczas gdy lepiej byłoby pewnie powiedzieć „Sąd oczyścił byłego prezydenta Olsztyna z jednego zarzutu molestowania, a sprawę dotyczącą drugiego umorzył z powodu przedawnienia”. Niektóre słowa były 
czasami źle odmienione; błędy te jednak najprawdopodobniej zostały poprawione w trakcie czytania, np.: „Protestujący domagają się m.in. zwiększenia budżetów komend i waloryzację wynagrodzeń”.

Mimo pozytywnej opinii na temat konstrukcji emitowanych informacji, należy wspomnieć, że zdarzały się też przypadki niezbyt atrakcyjnego przedstawienia wiadomości. Podanie w pierwszym zdaniu informacji, że coś się po prostu odbyło, nie jest najlepszym sposobem na zachęcenie słuchacza do wysłuchania dalszej jej części. Przykłady: „W Kętrzynie odbędzie się sesja Rady Miasta”, „W Kętrzynie odbędą się uroczystości”, „Trwają prace archeologiczne niedaleko dworca autobusowego". Przyjęło się też uważać, że tzw. informacja z dźwiękiem powinna kończyć się wejściem ze studia. $\mathrm{W}$ dwóch przypadkach stwierdzono jednak brak tzw. „zejściówki”.

Analizując informacje z 2015 roku, zwrócono także uwagę na fakt, że w serwisie podano bardzo ciekawą wiadomość na temat tego, jak proces byłego prezydenta miasta, Czesława Małkowskiego, i wyrok, który w tym czasie zapadł, wpływa na wizerunek miasta. Dziennikarze PAP pozbierali m.in. opinie przedstawicieli świata kultury, nauki, w tym osób, które niegdyś broniły publicznie byłego prezydenta. $Z$ pewnością na pochwałę zasługuje fakt, że dziennikarze Radia Olsztyn są czujni - wyszukali i podali tę informację w serwisie. $Z$ drugiej strony można zadać pytanie, dlaczego tego typu informacje są pozyskiwane niejako z drugiej ręki, a nie zbierane przez dziennikarzy Radia Olsztyn - w wersji dźwiękowej. Taka wiadomość byłaby z pewnością bardziej atrakcyjna.

Tak jak wspomniano wcześniej, w przypadku informacji z 2016 roku skupiono się raczej na błędach w zakresie prozodii przekazu i ocenie dźwiękowej warstwy prezentowanych informacji niż usterkach natury językowej - ze względu na dostępność materiału jedynie w wersji dźwiękowej, ich wychwycenie okazało się trudniejsze. Można jednak podać kilka przykładów także tego rodzaju błędów. Podobnie jak w przypadku 2016 roku zaobserwowano użycie strony biernej, np.: ,wniosek został złożony”. Znaleziono również przykłady użycia języka bardziej skomplikowanego, choć użycie prostszych odpowiedników było możliwe. Przykład: „kierowcy takimi drogami poruszają się wolniej”, zamiast po prostu: „jeżdżą wolniej”. Zdarzały się też przypadki użycia zaimków, które stanowiły tzw. „watę językową”; ich usunięcie nie zmieniłoby treści przekazu radiowego, np. informowano o przemytniku, który ukrył paczki papierosów „w swoim samochodzie” zamiast po prostu „w samochodzie”. Pojawiły się również błędy, które można określić jako błędy rzeczowe. Na przykład informowano, że więcej informacji można znaleźć „na fanpage'u i na Facebooku”, tymczasem wspomniany fanpage istnieje właśnie na Facebooku. Informację tę powtarzano bez korekty tego błędu.

Najczęstszym błędem w zakresie prezentacji dźwiękowej, który można było dostrzec $\mathrm{w}$ serwisach informacyjnych, były potknięcia podczas czytania. Zda- 
rzały się one wszystkim lektorom i trzeba je traktować jako coś naturalnego. Drugim problemem była sprawność dykcyjna lektorów. Pewne drobne usterki w tej materii są również czymś naturalnym. Problemem jest, gdy pojawiają się one zbyt często i łączą się z jakimś innym błędem związanym z emisją głosu, np. gospodarowaniem oddechem, a taki pojedynczy przypadek również stwierdzono. Poza niewyraźnym mówieniem zaobserwowano u lektorów również przykłady pomijania niektórych sylab w wyrazie.

Rzadko zdarzało się natomiast, by ktoś „przekręcił” słowo w serwisie i się nie poprawił czy też nie zamykał kadencji podczas czytania, czyli nie stawiał kropki intonacyjnej tam, gdzie ona występowała w tekście. Nie stwierdzono z kolei poważniejszych błędów w akcentowaniu wyrazów.

Osobną grupę błędów stanowiły błędy natury technicznej: np. podkład muzyczny stawał się głośniejszy w trakcie serwisu, nagranie wykorzystane w serwisie było nieodpowiednio zarejestrowane, dźwięk był źle przycięty lub dżingiel pojawił się w nieodpowiednim momencie.

Lektorzy z pewnością czytali tekst ze zrozumieniem, odpowiednio akcentowali najważniejsze części zdań; to ułatwiało słuchaczom przyswojenie przekazywanych informacji. Czasami można było jednak odnieść wrażenie, że prezentowali teksty w bardzo skonwencjonalizowany i poważny sposób. Jest to do pewnego stopnia zrozumiałe - serwisy są takim gatunkiem radiowym, w którym obowiązują pewne określone reguły i należy się ich trzymać. Radio jednak jest przede wszystkim medium mówionym i niekiedy można spróbować nieco wyłamać się z obowiązującej konwencji, np. poprzez nieco „weselszy”, pełen energii sposób czytania. Niektórzy lektorzy próbowali to robić, ale były to rzadkie przypadki.

W badanym materiale nie stwierdzono obecności komentarzy w prezentowanych informacjach, unikano nawet przymiotników o charakterze wartościującym [wyjątek stanowiło stwierdzenia typu „tragiczny wypadek”]. Można uznać to za przejaw dążenia dziennikarzy do tego, by przekazywane informacje były, zgodnie z oczekiwaniami słuchaczy, ,rzetelne i obiektywne”.

\section{Zrozumiałość prezentowanych informacji}

Radio jest przede wszystkim medium towarzyszącym. Słuchacze zazwyczaj nie koncentrują uwagi na treściach prezentowanych w radiu, gdyż robią w tym czasie coś innego. W przypadku radia nie ma też możliwości powrotu do tekstu informacji, jak to ma miejsce np. w prasie. Dlatego tak ważne jest, by informacje prezentowane w serwisach były zrozumiałe nawet po jednokrotnym przesłuchaniu. Do zbadania stopnia skomplikowania prezentowanych tekstów można wykorzystać wskaźnik mglistości Gunninga. Jego podstawą jest proste założenie - łatwiejsze w zrozumieniu są krótkie wyrazy i zdania niż długie, rozbudowane wypowiedzi. 
Tzw. wskaźnik mglistości Roberta Gunninga jest algorytmem, do którego podstawia się m.in. liczbę wyrazów trudnych [w języku polskim za słowa złożone uznaje się te, które składają się z czterech sylab i więcej] i liczbę wszystkich wyrazów w tekście. Uzyskany wynik wskazuje na przewidywaną liczbę lat nauki potrzebnych do zrozumienia tekstu.

Rysunek 1. Indeks czytelności FOG dostosowany do języka polskiego

$$
F O G=0,4\left(\frac{\text { liczba słów }}{\text { liczba zdań }}+100\left(\frac{\text { liczba słów długich }}{\text { liczba słów }}\right)\right)
$$

Wynik testu można interpretować zgodnie z poniższą tabelą:

\begin{tabular}{|l|l|}
\hline Wartość FOG & \multicolumn{1}{c|}{ Interpretacja } \\
\hline $1-6$ & język bardzo prosty, zrozumiały już dla uczniów szkoły podstawowej \\
\hline $7-9$ & język prosty, zrozumiały już dla uczniów gimnazjum \\
\hline $10-12$ & język dość prosty, zrozumiały już dla uczniów liceum \\
\hline $13-15$ & język dość trudny, zrozumiały dla studentów studiów licencjackich \\
\hline $16-17$ & język trudny, zrozumiały dla studentów studiów magisterskich \\
\hline 18 i więcej & język bardzo trudny, zrozumiały dla magistrów i osób z wyższym wykształceniem \\
\hline
\end{tabular}

Źródło: https://pl.wikipedia.org/wiki/Indeks_czytelno\%C5\%9Bci_FOG [dostęp: 20.05.2016].

By ocenić stopień zrozumiałości tekstów prezentowanych w serwisach informacyjnych Radia Olsztyn, wybrano losowo po dwie informacje z badanych serwisów z 2015 i z 2016 roku. W przypadku tych drugich, z uwagi na brak wersji pisanej, dokonano transkrypcji informacji. Do liczenia wykorzystano narzędzie internetowe dostępne na stronie http://www.trzyw.pl/gunning-fog-index/, które z uwagi na zautomatyzowany charakter generuje niekiedy wyniki nieznacznie różniące się od tych, które można uzyskać, licząc według podanego wzoru. Umożliwia jednak zorientowanie się, czy tekst należy do bardziej lub mniej zrozumiałych.

W przypadku losowo wybranej informacji z 2015 roku wyemitowanej 16 września 2015 roku o godzinie 12.00 uzyskano dobry wskaźnik 9,32, ale w przypadku drugiej informacji wyemitowanej 21 września 2015 roku w serwisie o godzinie 8.30 wskaźnik ten był jednak znacznie gorszy i wyniósł 16 . Liczenie ręczne wskazało nawet na wynik wyższy - ponad 17. W dość krótkim tekście znalazło się aż 17 słów zakwalifikowanych ze względu na swoją długość jako trudne w odbiorze. Były to następujące słowa: archeologiczne, niedaleko, autobusowego, przebudowy, kanalizacyjnej, znaleziono, ceramiki, fundamenty, nadzoruje, archeologiczna, badaniami, wydobyte, eksponaty, za- 
konserwowaniu, olsztyneckiego, kilkanaście, archeologów. W przypadku informacji wyemitowanej 15 kwietnia 2016 roku w serwisie o godzinie 12.00 uzyskano wskaźnik 6,98, a dla drugiej, wyemitowanej 18 kwietnia 2016 roku, o godzinie 8.30 - 7,81. Widać więc na tym przykładzie, że choć zazwyczaj dziennikarze Radia Olsztyn posługują się językiem zrozumiałym, to zdarza im się niekiedy przygotować informacje, które należałoby lepiej dostosować do możliwości odbiorców.

\section{Analiza czasu trwania serwisów}

Analiza czasu trwania serwisów Radia Olsztyn z 2016 roku pozwoliła stwierdzić, że liczyły one od 3'54" [serwis wyemitowany o 7.30, 13 kwietnia 2016] do 6'59" [serwis wyemitowany o 12.00, 15 kwietnia]. Najdłuższe były serwisy emitowane o godzinie 12 . To, na co z pewnością warto zwrócić uwagę, to fakt, że emisja serwisu sportowego po serwisie podstawowym nie wpływała na skrócenie długości serwisu podstawowego. Jeśli dany serwis podstawowy był z jakiegoś powodu danego dnia dłuższy, nie przekładało się to też na skrócenie długości trwania serwisu sportowego. Prowadziło to w skrajnych przypadkach do takich sytuacji, że np. serwis wyemitowany 13 kwietnia o godzinie 7.00 łącznie trwał 8'46" [6'06" minut trwał serwis główny i jeszcze dodatkowo 2'40" serwis sportowy].

\section{Porównanie serwisów Radia Olsztyn z 2015 i 2016 roku}

Podsumowujące porównanie pewnych ilościowych parametrów serwisów emitowanych w 2015 i 2016 roku nie pozwala stwierdzić jednoznacznie, które $\mathrm{z}$ nich zasługują na lepszą ocenę. Niektóre parametry wskazywałyby na wyższą jakość serwisów emitowanych w 2015 roku: przygotowano więcej informacji ogółem, więcej informacji lokalnych i więcej z nich było uzupełnionych o dźwięki. Wyemitowano też więcej relacji reportera i więcej informacji od dziennikarzy Radia Olsztyn zakupiła w tym okresie Informacyjna Agencja Radiowa. Z drugiej strony cechował je większy „olsztynocentryzm” [liczony jako stosunek informacji z Olsztyna do wszystkich wyemitowanych]. Mniejszy był też odsetek kobiet występujących w roli ekspertów. Wyemitowano również mniej informacji w najbardziej chyba atrakcyjnej dla słuchacza formie paszczodźwięku. 
Tabela 1. Porównanie informacji prezentowanych w serwisach Radia Olsztyn w 2015 i 2016 roku

\begin{tabular}{|l|c|c|}
\hline \multicolumn{1}{|c|}{ Kryterium porównania } & $\mathbf{2 0 1 5}$ & $\mathbf{2 0 1 6}$ \\
\hline Liczba informacji & 221 & 200 \\
\hline Liczba informacji lokalnych & 155 & 136 \\
\hline Liczba paszczodźwięków lokalnych & 2 & 6 \\
\hline Liczba lokalnych informacji z dźwiękiem & 81 & 69 \\
\hline Lokalne relacje reportera & 20 & $78 / 58$ \\
\hline Informacje z kalendarza & $98 / 57$ & $40 / 69(37 \%)$ \\
\hline Płeć ekspertów & $27 / 74(26 \%)$ & $50 / 136(38 \%)$ \\
\hline $\begin{array}{l}\text { Olsztynocentryzm (liczba/procent informa- } \\
\text { cji z Olsztyna) }\end{array}$ & $49 / 155(32 \%)$ & 19 \\
\hline $\begin{array}{l}\text { Liczba informacji, które kupiła Informacyj- } \\
\text { na Agencja Radiowa w tygodniach podda- } \\
\text { nych analizie }\end{array}$ & 24 & \\
\hline
\end{tabular}

Źródło: badania własne.

\section{Wnioski końcowe}

Serwisy informacyjne stanowią bardzo ważną część programu niemal każdej stacji radiowej. Jak podkreśla Grażyna Stachyra, mają bardzo istotny wpływ na kształtowanie wizerunku całej rozgłośni ${ }^{15}$. Nie ulega wątpliwości, że do tego elementu programu w Radiu Olsztyn przykłada się szczególną wagę. Świadczy o tym zarówno częstotliwość nadawanych serwisów [w dni powszednie nawet 28 razy na dobę], liczba nadawanych w poszczególnych serwisach informacji i ich rozbudowany charakter, jak i duża liczba dziennikarzy zaangażowanych w przygotowanie tej pozycji programowej, sieć korespondentów i studia lokalne w Elblągu i Ełku. Z pewnością serwisy te stanowią alternatywę dla tych przygotowywanych przez rozgłośnie komercyjne, w których to, jak zauważa Magdalena Steciąg, na plan pierwszy wysuwa się funkcja rozrywkowa ${ }^{16}$.

Ogólna ocena serwisów emitowanych w Radiu Olsztyn jest dobra i z pewnością rozgłośnia jest ważnym źródłem informacji lokalnych w regionie. Warto jednak spojrzeć też krytycznie na ich kształt, zwłaszcza pod kątem tematyki infor-

${ }^{15}$ Zob. G. Stachyra, Gatunki audycji w radiu sformatowanym, Wydawnictwo Uniwersytetu Marii Curie-Skłodowskiej, Lublin 2008, s. 130.

${ }^{16}$ Zob. M. Steciąg, Informacja, wywiad, felieton. Sposób istnienia tradycyjnych gatunków w radiu komercyjnym, Oficyna Wydawnicza Uniwersytetu Zielonogórskiego, Zielona Góra 2006, s. 209. 
macji pojawiających się w serwisach. Trzeba pamiętać, że informacja jako gatunek radiowy ma charakter najbardziej skonwencjonalizowany, łatwo tu popaść w rutynę - zarówno jeśli chodzi o sposób pisania informacji, jak i źródła, z których się je pozyskuje. Na ten problem nakłada się inny - osoby tworzące trzon redakcji informacji w Radiu Olsztyn wykonują tę pracę od kilkunastu czy też kilkudziesięciu lat. Przez ten czas z jednej strony nabrały ogromnego doświadczenia, z drugiej jednak wypracowały pewne bezpieczne schematy, z których korzystają. $\mathrm{O}$ ile sposób pisania informacji należy określić jako przyjemny dla ucha, zrozumiały, o tyle dobór informacji do serwisu cechuje silne skonwencjonalizowanie.

Tymczasem warto od czasu do czasu pochylić się nad procesem powstawania serwisu i spojrzeć nań nie tyle z perspektywy warsztatowej, ale jako na przestrzeń kreatywną. Ostatnio dużo mówi się o zaletach myślenia lateralnego, definiowanego jako zdolność tworzenia pozornie nieistniejących połączeń. To szukanie alternatywnych podejść - świadome rezygnowanie z gotowych rozwiązań na rzecz dążenia do znalezienia bardziej optymalnych, zmiana pewnych utartych konwencji w zakresie pozyskiwania informacji. W przypadku Radia Olsztyn owa zmiana mogłaby się przełożyć na zwiększenie atrakcyjności przygotowywanych serwisów. Warto też wziąć pod uwagę fakt, że świat się zmienia i źródła informacji się zmieniają. Tymczasem w badanym materiale nie stwierdzono np. ani jednej informacji inspirowanej wpisami lokalnych polityków, artystów czy działaczy w mediach społecznościowych czy na blogach lub powstałych na podstawie danych pozyskanych od słuchaczy. Nie prowadzono też badań dotyczących tego, czego słuchacze oczekują od serwisów informacyjnych w regionalnym radiu publicznym, na które przynajmniej część odbiorców wciąż płaci abonament. W badanych serwisach stwierdzono również bardzo małą liczbę lokalnych paszczodźwięków, które zalicza się do najbardziej atrakcyjnych radiowych gatunków informacyjnych.

\section{Bibliografia}

Beliczyński J., Misja i wizja regionalnego radia publicznego, „Studia Medioznawcze” 2006, nr 3, s. $32-47$.

Beliczyński J., Radio jako obiekt zarządzania, Wydawnictwo Akademii Ekonomicznej, Kraków 2005.

Chudziński E., Misja regionalnego radia publicznego, „Studia Medioznawcze” 2006, nr 3, s. 49-57.

Chudziński E., Regionalizm - idea - ludzie - instytucje, Muzeum Niepodległości, Mazowiecka Oficyna Wydawnicza, Warszawa 2013.

Kaszewski K., Elementy autoprezentacyjne w serwisie informacyjnym radia lokalnego, „Studia Medioznawcze" 2016, nr 1 (64), s. 89-103.

Kropacz-Szydłowska M., Od Ekspozytury Polskiego Radia do Radia Olsztyn S.A. Z dziejów olsztyńskiej radiofonii w latach 1952-1993, Polskie Towarzystwo Historyczne. Oddział: Instytut Dziennikarstwa i Komunikacji Społecznej UWM, Olsztyn 2012. 
Kwiatkowski M., Tu Polskie Radio Warszawa..., Państwowy Instytut Wydawniczy, Warszawa 1980. Langowski R., Pięćdziesięciolecie czyli podróż nieco sentymentalna, Pracownia Wydawnicza „ElSet”, Olsztyn 2002.

Ogrodziński W., Żmijewski B., Radio Olsztyn od 60 lat... naturalnie, Pracownia Wydawnicza „ElSet”, Olsztyn 2012.

Stachyra G., Gatunki audycji w radiu sformatowanym, Wydawnictwo Uniwersytetu Marii Curie-Skłodowskiej, Lublin 2008.

Steciąg M., Informacja, wywiad, felieton. Sposób istnienia tradycyjnych gatunków w radiu komercyjnym, Oficyna Wydawnicza Uniwersytetu Zielonogórskiego, Zielona Góra 2006.

\section{Netografia}

Indeks czytelności FOG, https://pl.wikipedia.org/wiki/Indeks czytelno\%C5\%9Bci FOG [dostęp: 20.05.2016].

KRRiT, Informacja o podstawowych problemach radiofonii i telewizji, 2005, http://www.krrit. gov.pl/Data/Files/_public/Portals/0/sprawozdania/spr2005/inf2005.pdf [dostęp: 20.05.2016].

Ustawa z dnia 29 grudnia 1992 roku o radiofonii i telewizji z późniejszymi zmianami, http://isap. sejm.gov.pl/Download?id=WDU20042532531\&type=3 [dostęp: 10.05.2015].

Urszula Doliwa

\section{News bulletins as an important element in the realisation of the mission of a regional radio broadcaster on the basis of Radio Olsztyn}

(Summary)

In accordance with the Act on radiophony and television a public broadcaster, such as the regional broadcasters of Polish Radio, is required to fulfil the so-called public mission. One important element of the programme which fulfilling this mission entails is the news bulletin. News bulletins emitted on Polish Radio Olsztyn in selected weeks of 2015 and 2016 are analysed. From this analysis, it emerges that particular attention is paid to this element of the programming in Radio Olsztyn. This is testified to both by the frequency with which bulletins are broadcast - as much as 28 times a day on weekdays, or the number of news items in each bulletin and their wide-ranging character, as well as the large number of journalists involved in the preparation of this scheduled item, the network of correspondents and local studios in Elbląg and Ełk. The radio station is an important source of regional and local information. However, although the method of preparing the information for the bulletins may be described as easy on the ear, their choice is typified by a high degree of conventionalisation.

Keywords: radio, public radio, regional broadcasters of Polish Radio, news bulletins. 